\title{
Assessment of Natural Hazards and Vulnerability in the Rio Copiapó Catchment: A case study in the ungauged Quebrada Cinchado Catchment $^{1}$
}

\author{
Michael Märker ${ }^{2,3}$, michael.maerker@geographie.uni-tuebingen.de; Friedrich Dangel², \\ María Victoria Soto Bäuerle ${ }^{4}$ and Giuliano Rodolfi ${ }^{2}$
}

\begin{abstract}
Intensive precipitations in desert areas are a very scarce phenomenon. Nevertheless, from time to time these events take place, as in 1997 in Southern Atacama Desert in Chile. The study area within the Copiapó catchment is intensively exploited by mining activities. However, in recent years the landscape has been more and more used for agricultural purposes. Vineyards for grape production are irrigated with water from the Copiapó River and from groundwater aquifers. The agricultural activity is mainly focusing on the flat valley bottoms, as well as drainage lines that become active in cases of precipitation events. Thus, this study seeks to investigate the geo-hazards related to precipitation events in order to quantify the risk for population and agricultural areas. Therefore, this study applies a hydrological model calibrated in the ungauged basin of Quebrada Cinchado. The results demonstrate that events like the one on the 12.06 .1997 generate intensive floods and related sediment discharges that endanger population and agricultural areas. The applied methodology allows quantification of flooding and mudflow risks, as well as to assess the spatial distribution of geo-hazards.
\end{abstract}

Keywords: Atacama Desert; hydrological model; floods; mudflows

\section{Evaluación de las amenazas naturales y de la vulnerabilidda en la Cuenca del río Copiapó: El caso de estudio de la subcuenca Cinchado}

\section{RESUMEN}

Las precipitaciones intensas en zonas desérticas son un fenómeno escaso. Sin embargo, cada cierto tiempo estos fenómenos pueden ocurrir, como sucedió en el año 1997, en la zona sur del Desierto de Atacama, Chile. El área de estudio, la cuenca del río Copiapó es un área intensamente explotada con fines agrícolas, con viñedos para la producción de uva de mesa de exportación, que son regados con agua del río Copiapó y de los acuíferos subterráneos. La actividad agrícola se centra principalmente en el fondo de valle, en laderas y conos aluviales, como también en subcuencas que se activan en caso de eventos de precipitación concentrada. Consecuentemente, se investigan los geo-amenazas relacionadas con los eventos de precipitación a fin de poder evaluar el riesgo para la población y las zonas agrícolas asociadas. Se aplicó un modelo hidrológico y se calibró en la cuenca de la Quebrada de Cinchado, afluente esporádico del río Copiapó. Se evidencia que eventos climáticos como los de las inundaciones de junio de 1997 pueden generar inundaciones y descargas de sedimentos que ponen en peligro a la población y las zonas agrícolas. La metodología aplicada permite la cuantificación del riesgo de inundaciones y flujos de barro como también evaluar la distribución espacial de los peligros de origen natural.

Palabras claves: Desierto de Atacama; Modelo hidrológico, inundaciones, flujo de barro

Recibido el 25 de junio de 2012, aceptado el 26 de noviembre de 2012.

\section{Proyecto FONDECYT 1071098}

Department of Earth Sciences, University of Florence, Italy. Via La Pira 4, 50121, Firence.

Department of Physical Geography, University of Tübingen, Germany.

4 Department of Geography, Faculty of Architecture and Urbanism, University of Chile, Chile. 


\section{INTRODUCTION}

The marginal desert environment of the Copiapó valley in the Atacama Desert is characterized by evolutionary morphological traits of an inherited landscape, highlighting forms associated with the action of water, expressed by intense slope dissection, as well as prominent alluvial deposits forming relict slopes, as described for the Chilean Semiarid regions by WEISCHET (1968). CASTRO et al. (2009) found that there are landscape dynamics associated with El Nino events, generating increased landscape vulnerability.

Generally the natural conditions are reflected in production systems, which are related to a strong seasonal production of vines. During El Niño events, basins activities reactivate and lead to great torrential flows, as recorded by VILES and GOUDIE (2003) in IRIBARREN (2007) in semiarid Andean basins of Chile. Environments where climate is characterized by scarce or erratic precipitations are classified as sensitive, since sporadic intense precipitations significantly accelerate soil erosion (RODOLFI, 2006). These conditions are given especially in the Chilean semiarid regions when El Nino fluctuations take place.

Despite the fact that the Atacama Desert in the north of Chile is one of the driest places on earth, it happens from time to time that vast amounts of rainfall cause runoff and generate flash floods that form a major threat for people living or working in these areas. In February 2001, many parts of the northern Atacama Desert were affected by large floods, resulting from heavy rainfall associated to La Nina, which caused lots of infrastructural damage (HOUSTON 2006). In June and August 1997 flooding occurred in the Copiapó area after a few hours of heavy rain. The floods caused damages on many buildings in the urban area. Despite the risk for residents, those floods also destroyed huge agricultural areas and caused severe damages. Particularly most of the alluvial areas in the valley of the Río Copiapó are used for grape production. These grapes are grown as cash crops that are more and more exported abroad. The Atacama region exports $98,8 \%$ of grapes to the international market. To satisfy the growing demand for cheap grapes, the farmers cultivate all available flat areas in the Copiapó valley that can be irrigated efficiently by water from the Copiapó River and ground water (DIRECCIÓN GENERAL DE AGUAS 2004). On the one hand, these activities created lots of jobs in the agricultural sector and reduced the dependency on mining which is the biggest economic sector in the region. However, most of the agricultural areas lie in potential geo-hydrological hazard zones. In case of a severe flood event in the Copiapó valley or in one of the neighboring watersheds, wide areas of agricultural activity could be destroyed by torrential flash floods with great economic loss as a consequence.

Most of the heavy rains in the Atacama are related to El-Nino/ Southern Oscillation Phenomena (ENSO) and occur during the southern hemisphere summer (CAVIEDES 2005). Though, flood events can also be generated by La Nina event as shown by HOUSTON (2006a). Due to these specific climatic pattern related to $\mathrm{La}$ Nina/ El Nino, extreme droughts or floods may occur according to the characteristics of the affected regions (KANE 2006). The rain in Copiapó is generally stronger in El-Nino/ La Nina years, but most of it occurs during the winter months from June to August when low-pressure areas from the south reach to the southern parts of the Atacama Desert (HOUSTON 2006).

For instance, in 1997 El Nino caused extreme precipitation events in Brazil, Paraguay, Uruguay, North-eastern Argentine and Chile. The Atacama Desert was blooming again in 1997 after 40 years (KANE 2006). These extreme events represent not only a 
threat in terms of flooding, flash floods, mudflows and landslides endangering human life, but also in terms of financial and economic losses. The socio-economic loss in 1997 in Venezuela, Colombia, Bolivia, Ecuador and Peru was calculated up to US \$2.5 Billion (SANTOS 2006). In 1997, in the Copiapó region, the Elibor Campamento Station, which is $30 \mathrm{~km}$ south of Copiapó, measured a monthly precipitation of $109 \mathrm{~mm}$ in June and 92 $\mathrm{mm}$ in August. In comparison, the average yearly rainfall is $12 \mathrm{~mm}$. In June and August 1997 most of the precipitation was falling in just a few hours, consequently, large flood events were generated with related damages (Fig. 1).

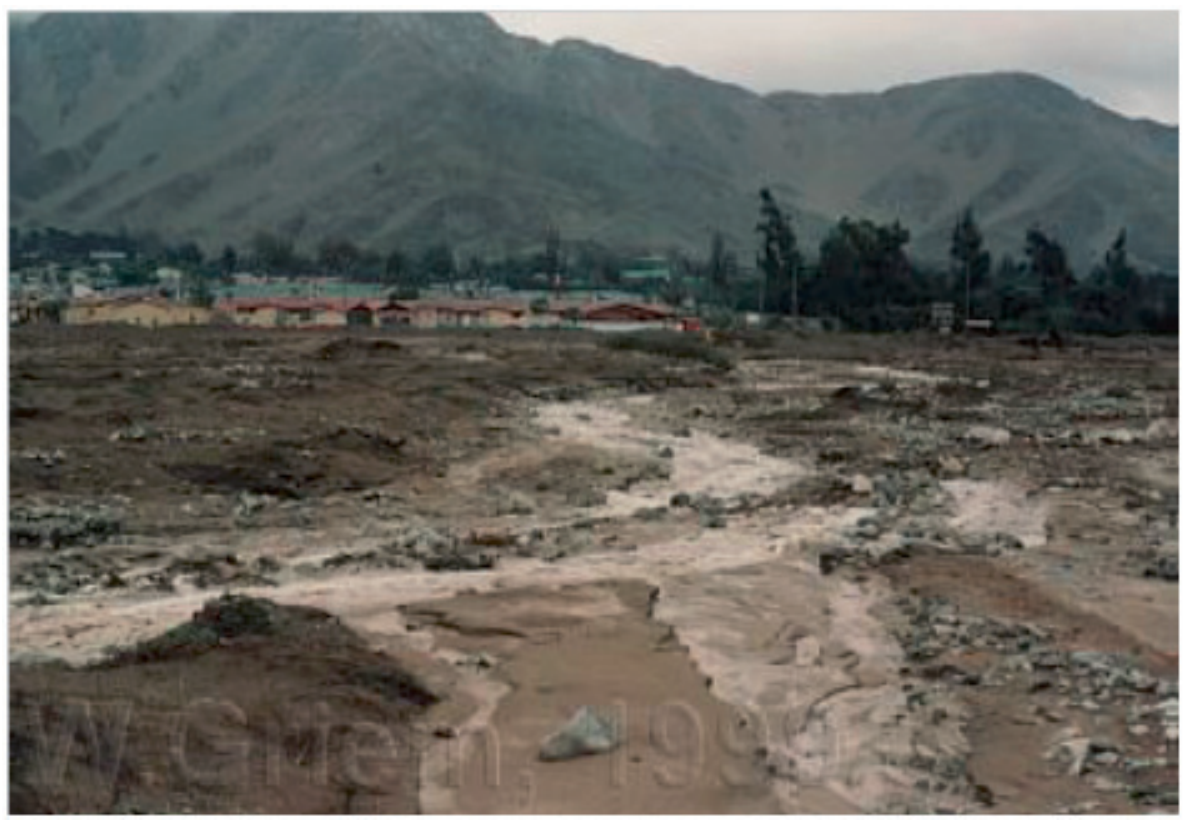

Fig. 1. Mud flow deposits in the vicinity of Copiapó after the precipitation in June 1997. Source: Museo Virtual de la Región Atacama (geovirtual.cl)

Fig. 1. Depósitos de flujos de lodo en las cercanías de Copiapó después de las precipitaciones de junio de 1997. Fuente: Museo Virtual de la Región Atacama (geovirtual.cl)

Already after $10 \mathrm{~mm}$ precipitation events, surface runoff makes roads impassable and water is ponding in areas with no or bad drainage. In the future, settlement and economic activity will grow, especially in regions exposed to hazard due to an increasing demand on cheap land and higher frequency and magnitude of extreme events (MÜNCHNER 2005). Therefore a quantification of the risk for settlement areas and agricultural land is not only economically interesting but also highlights the related risk for the local population.

This study examines torrential rains in an ungauged tributary of the Copiapó River and assesses their impacts on runoff, erosion and depositional processes. Moreover, we quantify the magnitude of the flooding events and evaluate the consequences for farmers and residents in the area. 


\section{MATERIALS AND METHODS}

\section{Study area}

The analysis focuses on the Quebrada Cinchado micro watershed, tributary of the Copiapó River. The selected area corresponds to a sector that underwent major changes in relation to the original desert landscape due to the installation of vine yards to produce grapes that are exported as cash crop. The study basin is regarded as a representative basin of the middle section of the Copiapó valley. In terms of the physical characteristics and the morpho-climatic domain it may account for some recurring dynamic patterns in the larger Copiapó River system.

The landscape is typical for the Andean mountain desert areas characterized by a medium altitude level. The watershed drains through structural monoclinal slope systems developed in detrital volcanic rock sequences (Cretaceous, AREVALO, 2005). These slope systems are representative concerning the marked weathered outcrops towards the talwegs. On top of these slopes Miocene gravel deposits constitute the highest erosion surfaces. Consequently, these top surfaces are rather smooth. The talweg of Cinchado is active only during El Nino rainfall events. Figure 2 shows the catchment of the Copiapó River and the study area (black line). Mean annual precipitation is about $12 \mathrm{~mm}$ but this varies according to El Nino/La Nina activities. Mean annual temperature is about $28^{\circ}$ with maximum values in January.

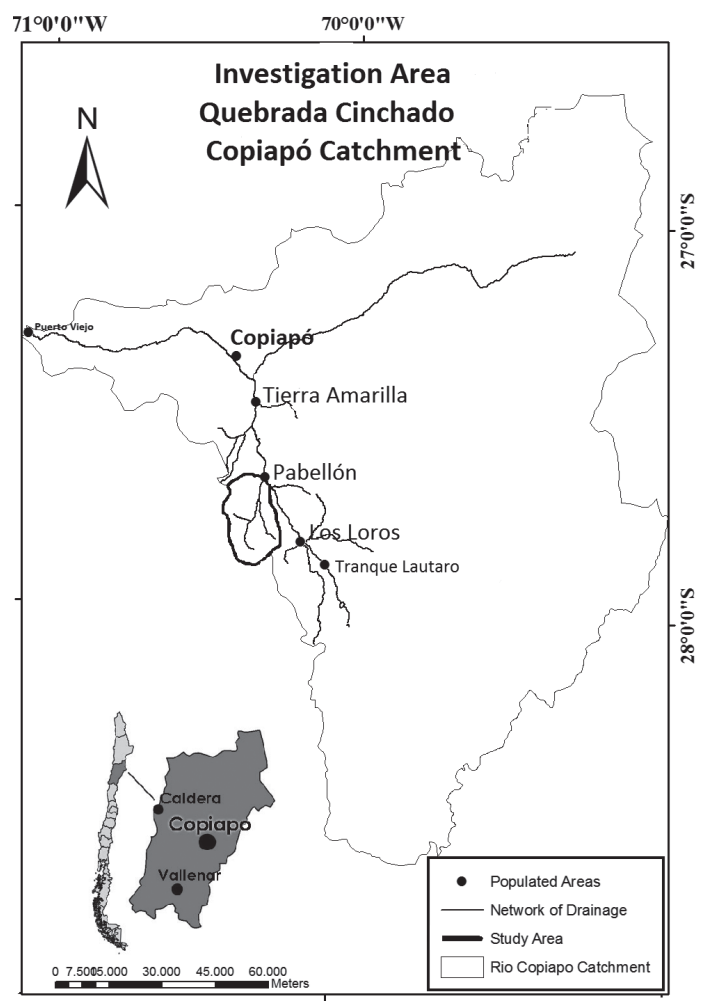

Fig. 2. Study area

Fig. 2. Área de estudio 
Data about the maximum daily precipitation for the meteorological station of Elibor Campamento, $30 \mathrm{~km}$ south of Copiapó, provides the base for the estimation of runoff during one storm event and it also helps to assess the rainfall amount of a 100-year storm and the related discharges. The rainfall used in this study represents the highest amount of precipitation ever recorded in this area, fallen on the $12^{\text {th }}$ of June in 1997 and amounting to $92.4 \mathrm{~mm}$. According to the frequency analysis, this rainfall has a return period of 61 years. This data is used as input for modeling of runoff and erosion processes in the Quebrada Cinchado catchment with a surface area of approx. $250 \mathrm{~km}^{2}$ and the outlet near Pabellón $\left(27^{\circ} 40^{\prime} 21^{\prime \prime}\right.$ lat S; $70^{\circ}$ 14'21'” long W) (Fig. 2).

For the erosion hazard assessment the Unit Stream Power - based Erosion Deposition Model (USPED) (MITASOVA et al., 1996) was applied. USPED uses the same input factors as the RUSLE (RENARD et al., 1991), but it additionally implies the topography (curvatures) and uses the transport capacity of water to gain information about erosion and deposition. With information about the erosion and deposition processes it is possible to estimate the damages caused on agricultural areas. The input information about the soil erodibility was derived by soil texture analysis, organic content and soil structure and permeability measurements (KUNTZE et al., 1994). Therefore 12 representative profiles following a catena approach (CONACHER \& DALRYMPLE 1969) were analyzed. C-factor values were set to 1 since an analysis of NDVI values using ASTER multispectral data yield a vegetation cover that is less than $1 \%$ of the total area. The topographic factor was derived from a digital elevation model (ASTER GDEM) with a $30 \mathrm{~m}$ resolution. Subsequently, the Topographic Wetness index was calculated according to BEVEN \& KIRKBY (1979) (see also WILSON \& GALLANT 2000). The support practice factor is not relevant in the area and hence, set to 1 . R-factor was calculated for the Elibor Campamento Station based on a $92.4 \mathrm{~mm}$ precipitation within 11 hours. R-factor was calculated to values of 42.53 hundreds of ft-tons/acr.

In order to figure out if there are shallow landslides endangering agricultural areas and people working there, the Stability Index Mapping Extension (SINMAP) (PACK et al., 2005) for ArcGIS was used to calculate the factor of safety as a proxi for a potential land slide hazard in the catchment area. To set up the model there is the assumption of quite homogeneous geotechnical characteristics of the Quebrada Cinchado catchment. The parameters utilized for soil density were measured at the field and set to $1500 \mathrm{~kg} / \mathrm{m}^{3}$. The repose angle was set to $40^{\circ}$ according to the catchment substrates. All other parameters were kept constant following the default values given by the model.

Since there was almost no information about the hydrology of the study area of Quebrada Cinchado, a hydrological model was utilized (TOPMODEL, BEVEN \& KIRKBY 1979; BEVEN 1998) to estimate the runoff. TOPMODEL is a hydrological model that is based on topography, and hydrological processes are simulated according to physical laws (WHEATER et $a l ., 2008$ ). The model uses input parameters that are directly measurable like infiltration, hydraulic conductivity, soil water deficit, soil depth, etc. This type of model has the advantage that the hydrology of a catchment can be modeled without knowing the exact discharge. Thus, the model is able to simulate runoff characteristics of ungauged basins.

To calibrate the model the study is based on several assumptions. Thus, the only runoff tracers in the Quebrada Cinchado were micro terraces that were surveyed along a $10 \mathrm{~km}$ longitudinal profile on both sides of the flood plain. Because no dating of the terraces were possible we hypothesize that the 12.06.1997 runoff event reached the height of the terrace embankment varying from a few centimeters in the upper parts 
of the catchment to more than $2.5 \mathrm{~m}$ close to the outlet. In total there were 500 cross profiles surveyed. Finally, the model calculations were made based on i) the runoff cross sections; ii) approximated runoff velocities, and iii) the runoff volume for two calibration sections as shown in figure 3 (yellow and green area). The calibration was performed by choosing the input parameters of TOPMODEL in a way that runoff volumes for the two calibration sections correspond with the height of the terrace profiles. During a field trip additional soil information was collected like grain-size distribution, content of organic matter and surface infiltration. Moreover evaporation was estimated using the mean potential evaporation at the meteorological station of Elibor Campamento (1396 mm/year). The precipitation input was only available in daily time steps. Thus, a precipitation scenario according to local observations was generated, as shown in figure 4. This scenario is consisting in two maxima one at the beginning and one after three hours.
The runoff volume was calculated based on the cross sections that are defined by the height and width of the micro-terraces. Figure 4 illustrates the runoff volumes generated on the 12.06.1997 for the two calibration cross sections. As shown, runoff occurs only three hours after the first precipitation event and is falling together with the second precipitation maximum. Thus, infiltration excess runoff is formed and the second precipitation peak increases the runoff. Consequently, the hydrograph is characterized by a steep runoff increase with values of $33,91 \mathrm{~m}^{3} / \mathrm{sec}$ in the small and $86.91 \mathrm{~m}^{3} / \mathrm{sec}$ in the large calibration catchment. This is a frequently observed phenomenon in desert areas where floods suddenly take place and move down the drainage network (e.g. BESLER 1992). After the maximum rainfall is decreasing, runoff also decreases. However, the second runoff maximum occurring after 5.5 hours is reached quicker than the first peak due to the fact that the shallow soils are already saturated.

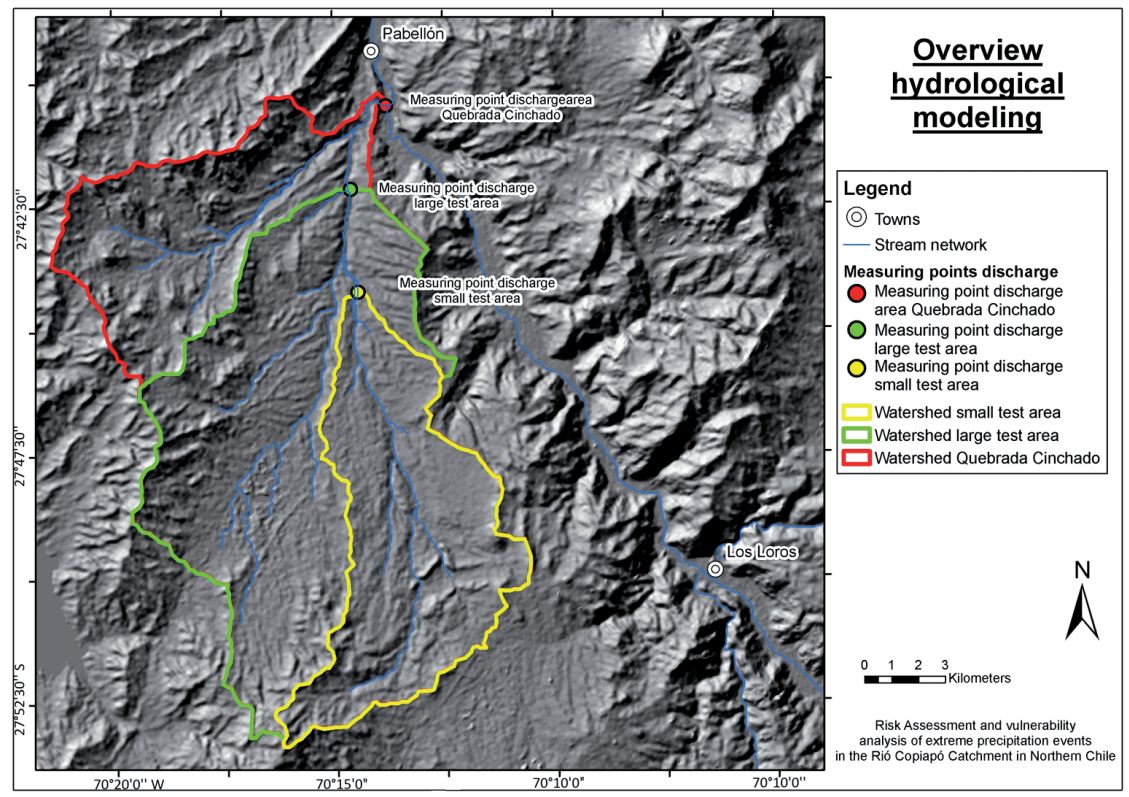

Fig. 3. Catchment area of the Quebrada Cinchado (red) and the catchments of two calibration sections (green and yellow). Source: Dangel (2009).

Fig. 3. Cuenca de la Quebrada Cinchado (rojo) y dos cuencas de calibración (verde y amarillo). Fuente: Dangel (2009). 


\section{RESULTS AND DISCUSSION}

The runoff volume was calculated based on the cross sections that are defined by the height and width of the micro-terraces. Figure 4 illustrates the runoff volumes generated on the 12.06 .1997 for the two calibration cross sections. As shown, runoff occurs only three hours after the first precipitation event and is falling together with the second precipitation maximum. Due to infiltration excess runoff is formed, whilst the second precipitation peak increases the runoff. Consequently, the hydrograph is characterized by a steep runoff increase with values of $33,91 \mathrm{~m}^{3} / \mathrm{sec}$ in the small and $86.91 \mathrm{~m}^{3} / \mathrm{sec}$ in the large calibration catchment. This is a frequently observed phenomenon in desert areas where floods suddenly take place and move down the drainage network (e.g. BESLER 1992). After the maximum rainfall has decreased, runoff also decreases. However, the second runoff maximum occurring after 5.5 hours is reached quicker than the first peak due to the fact that the shallow soils are already saturated.

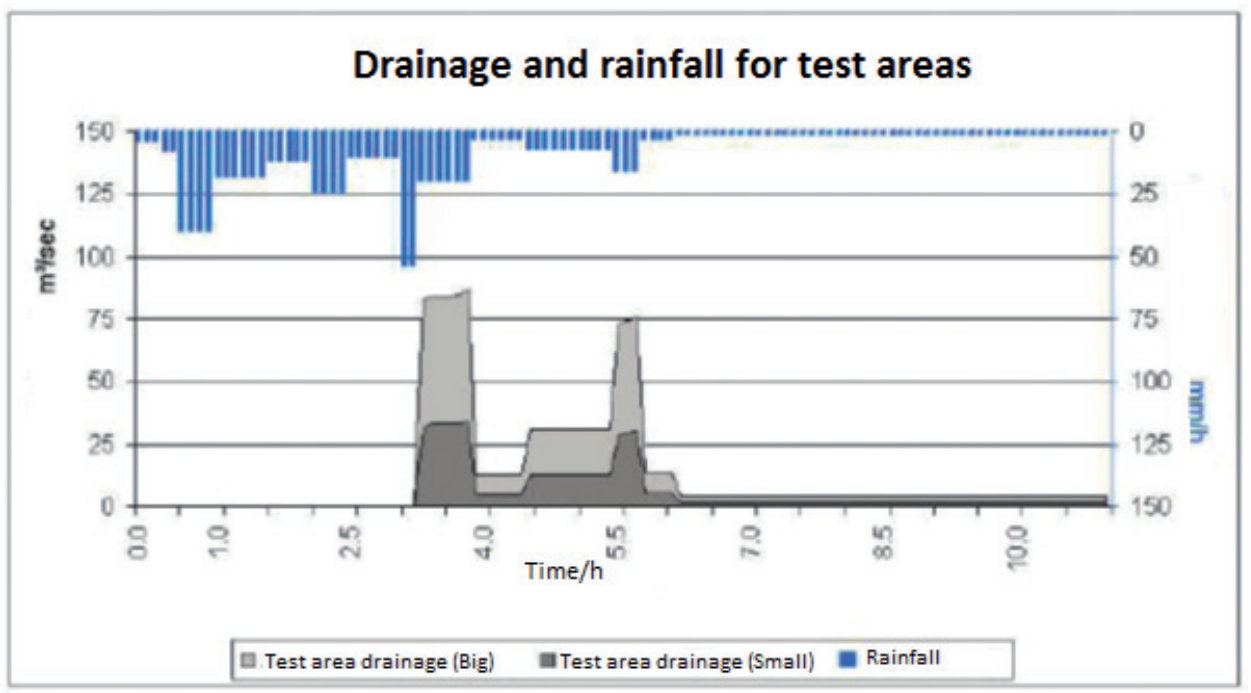

Fig. 4. Discharge and rainfall for the two small test catchments.

Fig. 4. Caudales y precipitaciones en dos pequeñas cuencas de testeo.

After calibration of the hydrological model the maximal discharge calculation was made for the entire Quebrada Cinchado (see Fig 5). The highest runoff was also registered more than three hours after the precipitation event with maximum runoff volumes of $108 \mathrm{~m}^{3} / \mathrm{sec}$. This represents a severe hazard for the population and the agricultural activities in the lower Quebrada Cinchado. 


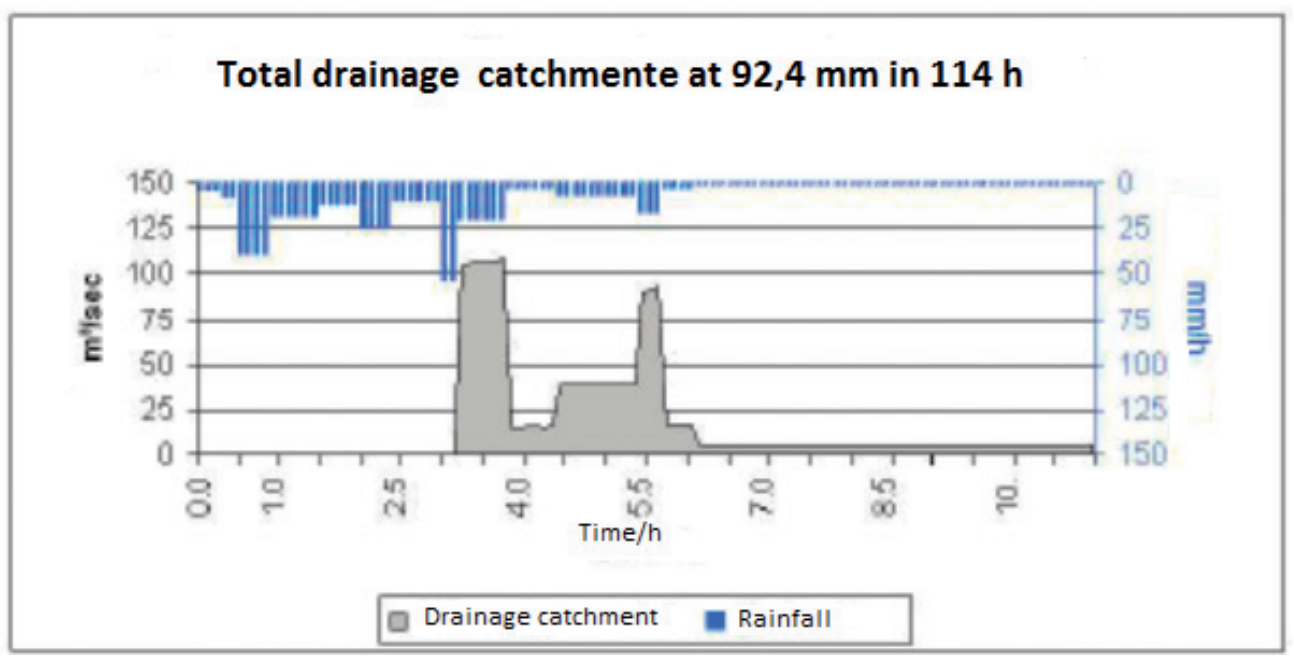

Fig. 5. Modeled runoff for a $92,4 \mathrm{~mm}$ event, in $\mathrm{m}^{3} / \mathrm{s}$ instead of drainage catchments.

Fig. 5. Escurrimiento modelizado para un evento de $92,4 \mathrm{~mm}$, en las cuencas de drenaje, en $\mathrm{m}^{3} / \mathrm{s}$.

With an assumed precipitation event that exceeds the $92.4 \mathrm{~mm}$ event by $50 \%$ $(138.6 \mathrm{~mm})$ the model yields a maximum runoff of about $488 \mathrm{~m}^{3} / \mathrm{sec}$. (Fig.6). This is four times more than for the $92.4 \mathrm{~mm}$ event as shown in Fig. 6. Moreover the maximum values in runoff are reached much earlier compared to the $92.4 \mathrm{~mm}$ event. This is due to infiltration excess and quicker saturation of the soil. However, it has to be taken into account that the model setting is conservative in terms of infiltration values. Hydrophobicity or bio crusting was not taken into account; it normally reduces infiltration and hence increases runoff. Consequently, high amounts of water reach the valley outlet and destroy plants on farmland and even represent a major threat for humans remaining in the flooding area. Calculations show that in case of an event exceeding the 1997 rainfall, the runoff rise significantly and thus, represents a severe hazard for the population and the agricultural activities in the lower Quebrada Cinchado. Concerning the agricultural activities the first grapes can only be harvested 5 years after planting. This means, that if wine yards are damaged, more than 5 years are needed to restore the activity. Figure 7 shows the areas that are located up to half a meter above the drainage network (in red) and hence are at severe flooding risk under conditions like the 1997 event. 


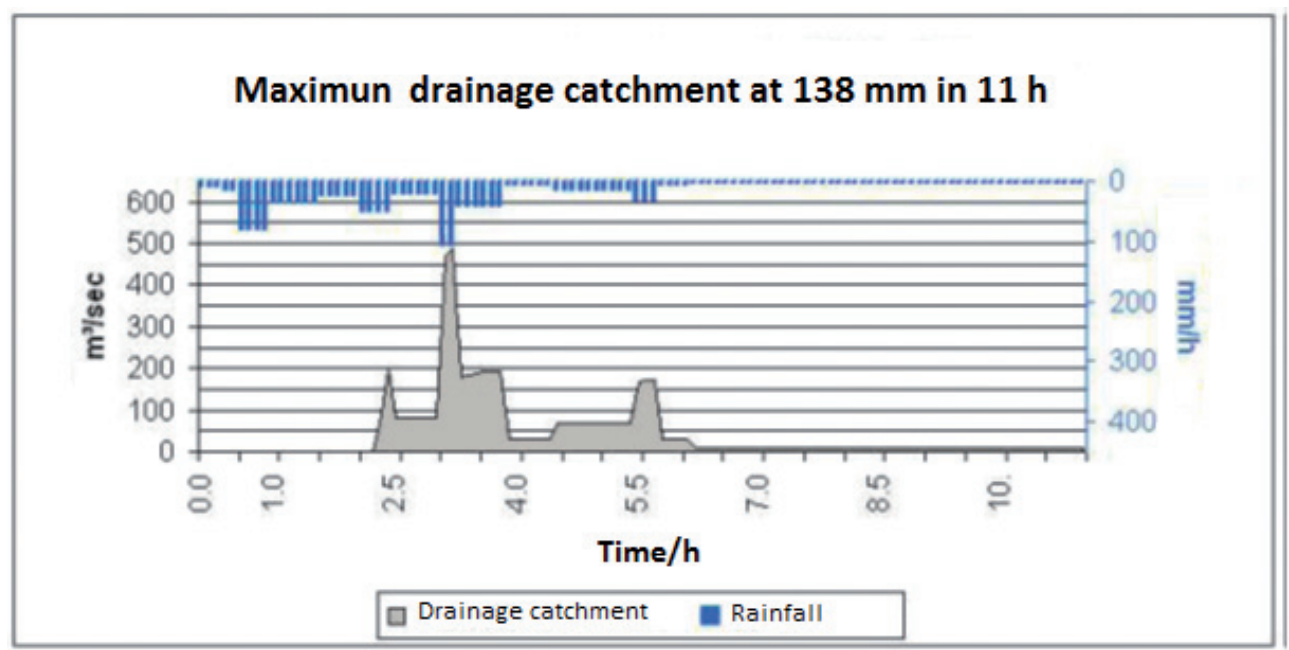

Fig. 6. Modeled runoff for a $138.6 \mathrm{~mm}$ event, in $\mathrm{m}^{3} / \mathrm{s}$ instead of drainage catchments.

Fig. 6. Escurrimiento modelizado para un evento de $138,6 \mathrm{~mm}$, en las cuencas de drenaje, en $\mathrm{m}^{3} / \mathrm{s}$.

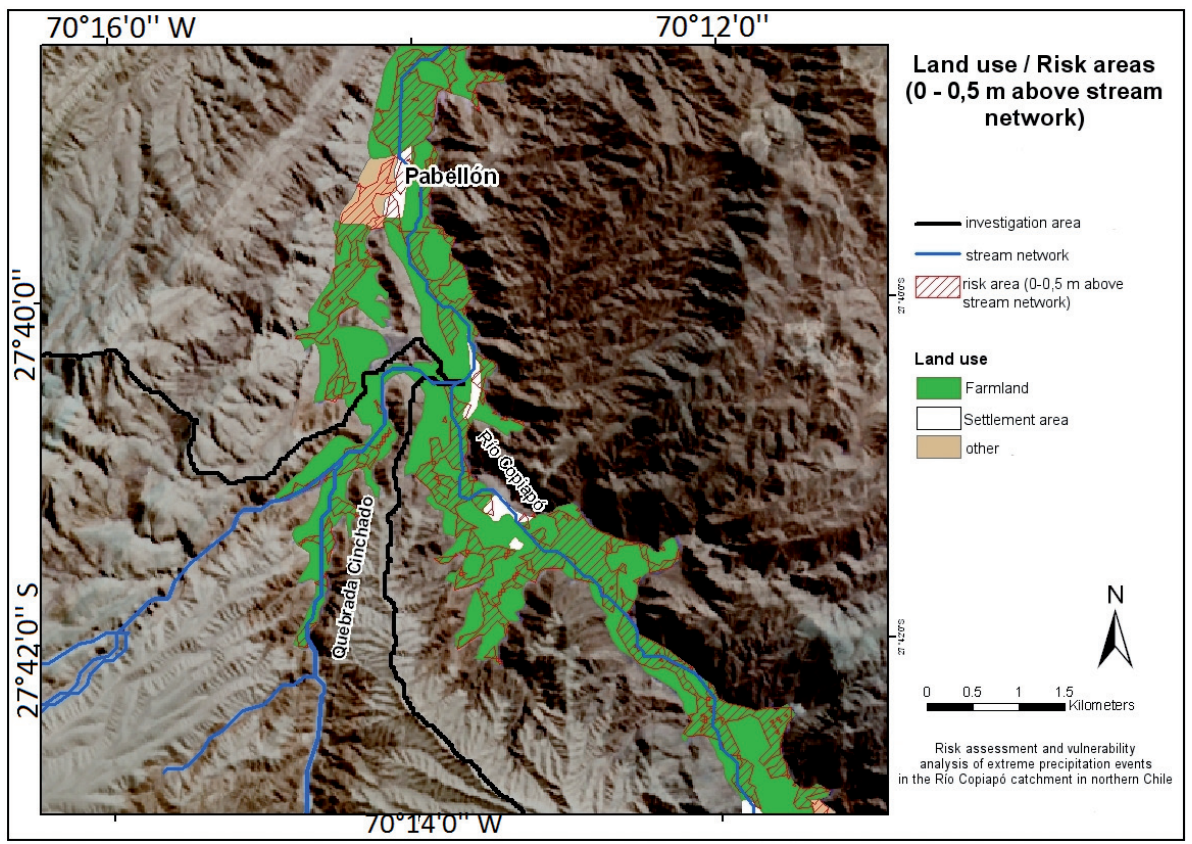

Fig. 7. Flood risk areas (red hachures) and main land use in the Copiapó valley. Source: Dangel (2009).

Fig. 7. Áreas de riesgo de inundación (achurado rojo) y principal uso del suelo en el valle de Copiapó. Fuente: Dangel (2009). 
Apart from the water that is accumulated along the river network and thus, generating concentrated runoff with high energy, soil is also eroded and sediments are transported with the runoff. During the 1997 event high sediment concentrations were deposited in areas where transport energy is low (Fig.1).

The soil erosion and deposition processes modeled with USPED for the Quebrada Cinchado catchment, shows that $71 \%$ of the entire area is affected by erosion whereas deposition occurs on $29 \%$ of the area. On average more sediment are eroded than deposited. Consequently, a large part of the sediments are washed off to the Copiapó River catchment.

Figure 8 (left side) illustrates the spatial distribution of erosion and deposition areas. Generally, high erosion rates are modeled along the drainage network. However, in flat drainage sections high deposition values can be observed. Hence, valley bottom areas are prone to very high morpho- dynamics during runoff events. In the case of Quebrada Cinchado agricultural activity is mainly concentrated on the valley bottom areas. As shown in figure 8 these areas are at a very high risk concerning flooding, erosion and sedimentation processes.

Parts of the sediments that are transported within the drainage network are the result of sheet and rill erosion processes. However, high amounts of sediments can reach the drainage system due to land sliding that may result in mudflows or hyper-concentrated flows. To assess landslide hazards the SINMAP model was applied. Figure 8 (right side) shows the spatial distribution of slope stabilities that are a proxy for land sliding hazard. Instable, sliding prone, slopes were especially located on the western slopes of the lower Quebrada Cinchado catchment. The spatial distribution of instable areas close to the river network enhances the already high risk presented in the valley bottom areas of the lower catchment.

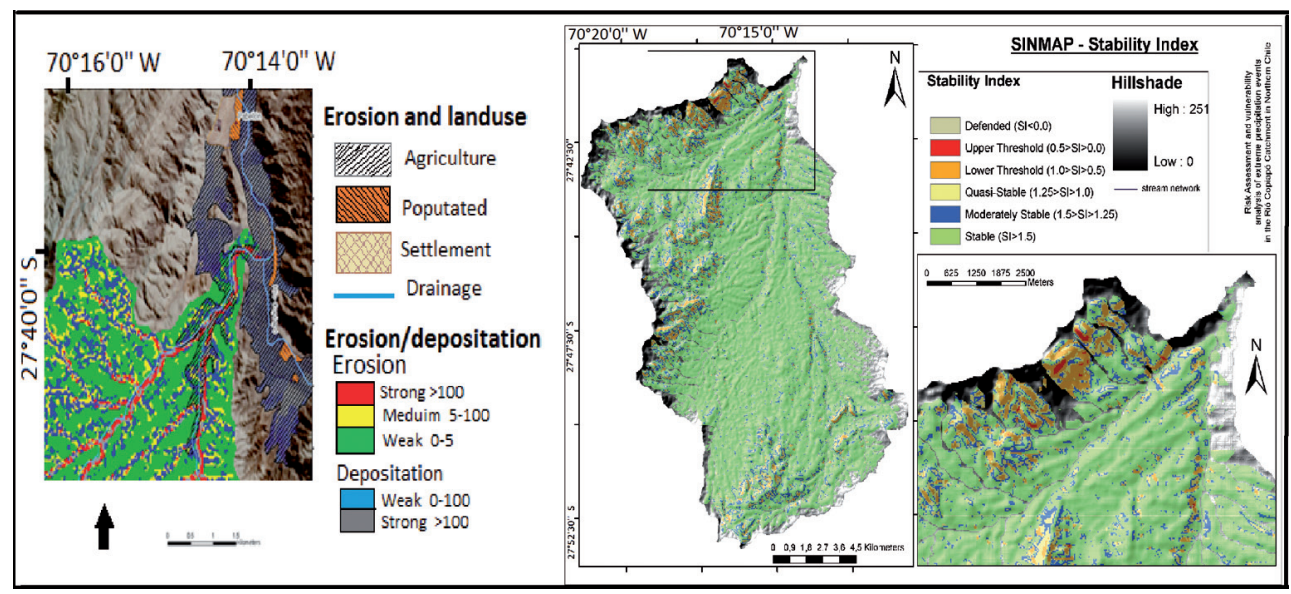

Fig. 8. Left: Soil erosion and deposition in the lower Quebrada Cinchado. Right: Slope stability model based on SINMAP application. Source: Dangel (2009).

Fig. 8. Izquierda: Erosión y depositación de suelos en la sección más baja de la Quebrada Cinchado. Derecha: Modelo de estabilización de las vertiente, basado en una aplicación SINMAP. Fuente: Dangel (2009). 


\section{CONCLUSIONS}

Although heavy storms have a recurrence period of several years or decades, they represent a major threat for the people and the economy in affected areas. With the expansion of the irrigated agricultural areas to the neighboring watersheds of the Río Copiapó, the likelihood of being affected by erosion or flooding events rises significantly. The application of quantitative methods allows assessing the risks related to geohydrologial hazards. Although the analysis are based on different hypothesis, the study demonstrates that even in ungauged basins with field observations and measurements the main input parameters can be estimated. The models allowed identification of high risk areas in the Quebrada Cinchado, concerning flooding, mudflows, erosion and sedimentation. The study also shows that scenarios like an increase of $50 \%$ of the 12.06.1997 precipitation lead to exponential higher runoff volumes. Thus, the modeling approach is also able to assess consequences of future climate change.

\section{REFERENCES}

AREVALO, C., 2005. Carta Geológica de Chile. Serie Geología Básica. Gobierno de Chile, Servicio Nacional de Geología y Minas. $\mathrm{N}^{\circ} 91$.

BESLER, H., 1992. Geomorphologie der ariden Gebiete. Wissenschaftliche Buchgesellschaft, Darmstadt. 189pp.

BEVEN, K.J., 1998. Topmodel. In: HERSCHY, R. \& R. FAIRBRIDGE (ed.): Encyclopedia of Hydrology and Water Resources. 490-491.

BEVEN, K.J. \& M.J. KIRKBY, 1979. A physically-based variable contributing area model of basin hydrology. Hydrological Science Bulletin, 24: 43-69.
CASTRO C. P., M.V. SOTO, R. FERNÁNDEZ, M. MÄRKER \& G. RODOLFI, 2009. Impacto en la geodinámica actual del valle de Nantoco, cuenca del río Copiapó, asociado a la reconversión productiva. Revista de Geografía Norte Grande, 42:81-99.

CAVIEDES, C.N., 2005. El Nino - Klima macht Geschichte. Primus, Darmstadt, $167 \mathrm{pp}$.

CONACHER, A.J. \& J.B. DAYLRYMPLE, 1977. The Nine Unit Landsurface Model: an approach to pedogeomorphological research. Geoderma, 18 (1/2.): 1-154.

\section{DIRECCIÓN GENERAL DE AGUAS -} MINISTERIO DE OBRAS PUBLICAS. 2004. Cuenca del Río Copiapó - Diagnostico y clasificacion de los cursos y cuerpos de agua segun objetivos de calidad. Santiago.

DANGEL, F. 2009. Phisich-geographische Risikobewertung und Vulnerabilitätsanalyse im Einzugsgebiet des Río Copiapó, Nordchileunpublished Msc Thesis, University of Tübingen, Department of Geography, Tübingen, inédito.

HOUSTON, J., 2006a. Variability of precipitation in the Atacama Desert - Its causes and hydrological impact. International Journal of Climatology, 26: 2181-2198.

HOUSTON, J., 2006b. The great Atacama flood of 2001 and its implications for Andean hydrology. Hydrogeological Processes, 20: 591-610.

IRIBARREN, P. 2007. Glaciares rocosos en el semiarido chileno, su significado climático y geomorfológico. Análisis de caso. Cuenca superior del río La Laguna. Memoria para optar al título de Geógrafo. Facultad de Arquitectura y Urbanismo, Universidad de Chile, Santiago, inédito. 
KANE, R.P., 2006. El Nino effects on rainfall in South America: comparison with rainfalls in India and other parts of the world. Advances in Geosciences, 6:35-41.

KUNTZE, H., G. ROESCHMANN \& G. SCHWERDTFEGER, 1994. Bodenkunde. UTB, Stuttgart, 424 pp.

MITASOVA, H., J. HOFIERKA, M. ZLOCHA \& L.R. IVERSON, 1996. Modeling topographic potential for erosion and deposition using GIS. International Journal of Geographical Information Science, 10(5): 629-641.

MÜNCHNER, R. 2005. SchadenspiegelThemenheft Risikofaktor Wasser. München: 48. Jahrgang, 1- 48, 3/2005.

PACK, R.T., D. TARBOTON, C.N. GODWIN \& A. PRASAD, 2005. SINMAP 2 - A Stability Index Approach to Terrain Stability Hazard Mapping, technical description and user's guide for version 2.0. Utah State University. http://www. engineering.usu.edu/dtarb/sinmap.html.

RODOLFI, G. 2006. Erosione hídrica del suolo in ambiente mediterraneo: valutazione diretta e indirecta in aree Campione e Bacini idrografici. $1^{\circ}$ Ed. Genova. Ministero dell Universita e Della Ricerca Progetti di Rilevante Interesse Nazionale (PRIN/ COFIN 2002). Brigati, Genova.
SANTOS, J. L., 2006. The Impact of El Nino - Southern Oscillation Events on South America. Advances in Geosciences, 6:221-225.

WEISCHET, W. 1968. Zur geomorphologie des Glatthang-Reliefs in der ariden subtropenzone des Kleines Nordens von Chile. Zeitschrift fur Geomorphologie, 13 (1): 1-21.

WHEATER, H., S. SOROOSHIAN \& K.D. SHARMA, K. D, 2008. Hydrological Modelling in arid and semi-arid areas. Cambridge University Press, New York, $206 \mathrm{pp}$.

WILSON, J. P. \& J.C. GALLANT, 2000. Digital Terrain Analysis. In: Wilson, J. P. \& J.C. Gallant (Eds.) Terrain Analysis Principles and Applications. John Wiley \& Sons, Inc. Oxford:1-26. 